Infect Dis Clin North Am. 2014 December ; 28(4): 615-631. doi:10.1016/j.idc.2014.08.004.

\title{
Human Immunodeficiency Virus Vaccines
}

\author{
Paul Goepfert, MDa, ${ }^{*}$ and Anju Bansal, PhD ${ }^{b}$ \\ aDivision of Infectious Diseases, Department of Medicine, University of Alabama at Birmingham, \\ 908, 20th Street South, CCB 328, Birmingham, AL 35294, USA \\ bDivision of Infectious Diseases, Department of Medicine, University of Alabama at Birmingham, \\ 845, 19th Street South, BBRB 557, Birmingham, AL 35294, USA
}

\section{Keywords \\ HIV vaccines; Neutralizing antibodies; Binding antibodies; T cells; Viral vector; Protein boost; DNA prime}

\section{INTRODUCTION}

Despite tremendous advancements in the treatment of HIV-1 over the past 20 years, the number of new infections remains largely unchanged with an estimated 40,000 to 50,000 patients diagnosed annually with HIV infection in the United States ${ }^{1}$ and over 2 million worldwide. ${ }^{2}$ Up until recently, only behavioral modification modalities were effective in decreasing the number of new infections. ${ }^{3}$ Fortunately, recent studies have demonstrated the effectiveness of male circumcision, ${ }^{4-6}$ pre-exposure prophylaxis, ${ }^{7-9}$ and treatment of infected partners ${ }^{10}$ in significantly preventing HIV infection. Such improvements in therapeutic prevention modalities are likely to appreciably decrease the number of new HIV infections in the United States and globally. Nevertheless, based on the success of prior vaccines for many infectious diseases, an effective vaccine to prevent HIV infection and disease progression is thought to be the most effective potential weapon in controlling this global pandemic. ${ }^{11-13}$ Many licensed vaccines elicit immune responses that confer T-cellmediated and/or antibody-mediated protection from subsequent exposure. ${ }^{14}$ Both arms of the adaptive immunity are needed in a vaccine, especially when dealing with highly variable pathogens. The immune mechanisms by which this antiviral effect is achieved are shown in Fig. 1. Therefore, it is thought that for an HIV vaccine to be highly efficacious, it must elicit robust humoral and cellular immune responses. ${ }^{15}$

Despite early optimism, the development of an effective HIV vaccine has been extremely difficult. ${ }^{16,17}$ This cumbersome and lengthy process can take several years between transitioning from basic research to preclinical development to clinical trials. Furthermore, because HIV viral challenge is not possible, evaluation of vaccine efficacy in a high-risk group takes several additional years following the last vaccination. This evaluation is done

(C) 2014 Elsevier Inc. All rights reserved.

*Corresponding author: paulg@uab.edu. 
to determine whether the vaccine recipients engaging in high-risk activities have decreased infection rates compared with placebos. To confound the timeline of vaccine development even further, gauging a vaccine's efficacy using validated immune assays can take additional time.

Several approaches have been tried to elicit humoral and/or cell-mediated immune responses. These approaches include using DNA and recombinant viral vectors to deliver HIV-1 gene products ${ }^{18-20}$ as well as a protein boost using env-gp120. ${ }^{21}$ Nevertheless, a large number of preclinical and clinical studies have been performed with largely disappointing results to date. Only 4 distinct vaccine regimens have made it to clinical efficacy studies (Fig. 2), ${ }^{21-25}$ and only 1 of these 4 studies has been somewhat successful in preventing infection or clinical markers of disease progression (Fig. 3). ${ }^{25}$

The first attempt included 2 clinical studies ${ }^{26-28}$ that tested the efficacy of a bivalent monomer of the surface envelope glycoprotein (gp120). This design was tailored to induce type-specific antibody responses, a strategy that had worked for the hepatitis B vaccine. ${ }^{29-31}$ Initially, the HIV vaccine approach was evaluated in healthy HIV-seronegative men and women at high risk of infection in the Americas and Europe. Despite successes seen in community engagement, rapid enrollment, safety, and follow-up, desirable efficacy with this product was not achieved. ${ }^{23}$ A parallel study done in Thailand among intravenous drug users with a clade $\mathrm{B} / \mathrm{E}$ env vaccine demonstrated similar findings. ${ }^{21}$ Thus, although these 2 vaccines were safe, they did not elicit HIV-1-specific antibodies that effectively prevented infection. Because of the difficulties in generating antibodies that can bind and neutralize HIV virions, the focus of the HIV vaccinology field shifted toward generating T-cell responses.

The second vaccine regimen to be tested on a large scale consisted of a replication-defective adenovirus type 5 that encoded Gag, Pol, and Nef proteins. The inclusion of these immunogens that are not generally expressed on the surface of cells and lack Env in the vaccination regimen skewed the responses toward $\mathrm{T}$ cells, with the goal of preventing disease progression. This clinical trial was based on encouraging preclinical data in nonhuman primates, which showed that this vaccine induced potent T-cell responses, which did not prevent infection but controlled infection and protected against progression to AIDS. ${ }^{32}$ Nevertheless, clinical testing this vaccine strategy (the Step Study) failed to demonstrate protection against infection or clinical markers of disease progression in healthy men having sex with men (MSM). ${ }^{22}$ In fact, safety concerns were raised when it appeared that a subset of vaccinees were at higher risk of infection. ${ }^{33}$ The initial culprits for enhanced infection among vaccinees were thought to be high levels of pre-existing Ad5 antibody titers and/or lack of circumcision. Such concerns prompted stopping a sister study in South Africa (Phambili Study) before full enrollment. ${ }^{34}$

Despite the setbacks from the Step Study, another clinical efficacy trial (HVTN 505) that used rAD5 as a delivery vehicle was initiated. ${ }^{35}$ This trial differed from the Step Study in that multiclade Env was included to generate antibodies in addition to Gag and Pol proteins for eliciting T-cell responses. Furthermore, based on the lessons learned from the Step Study, HVTN 505 enrolled Ad5-seronegative and circumcised MSM. Unfortunately, this 
study was also stopped before full follow-up because of a lack of efficacy in preventing infection or lowering viral loads in the infected vaccinees. ${ }^{24}$ Fortunately, unlike the Step Study, there was no evidence of increased infection risk attributed to this vaccine.

The only vaccine study that has demonstrated some efficacy has been the RV144 Trial. ${ }^{25}$ The move to go ahead with this study was fraught with controversy because its components were each shown to be nonefficacious ${ }^{21,23}$ or poorly immunogenic by themselves, ${ }^{36,37}$ prompting many skeptics to oppose this vaccine concept. ${ }^{38}$ The study, conducted in Thailand, enrolled more than 16,000 men and women who were at increased risk of infection and vaccinated half of them with a recombinant canarypox vector encoding Env, Gag, and the protease of Pol boosted by this same vaccine combined with the bivalent gp120 used in the prior study in Thailand. ${ }^{21}$ The vaccine regimen provided modest efficacy of $31.2 \%$ in protection against infection but no decrease in viral load set point in those who were infected despite vaccination. ${ }^{25}$ Although the protection against infection just reached statistical significance, the findings were supported by a $60 \%$ efficacy 12 months following final vaccination, which subsequently waned. Follow-up analyses identified several immunologic correlates that were associated with the observed vaccine efficacy. ${ }_{39,40}$ Although weak neutralizing antibodies were induced, binding antibodies of the immunoglobulin $\mathrm{G}(\mathrm{IgG})$ subtype to variable loops 1 and 2 of Env (V1V2) were found to be most predictive of vaccine efficacy. ${ }^{41}$ Conversely, Env-specific plasma IgA antibodies targeting the $\mathrm{C} 1$ region directly correlated with infection rate. These $\operatorname{IgA}$ antibodies were not increasing the risk of infection but rather were diminishing the phagocytic enhancing effect of the V1/2-specific IgG antibodies. ${ }^{42}$ Among vaccinees who became infected, sieving studies showed that the vaccine "selected" a signature mutation in the V2 loop, further supporting the importance of antibodies against this region. ${ }^{43}$ Two recent studies have demonstrated that the $\operatorname{IgG} 3$ subtype was also associated with protection, suggesting that antibody-dependent cellular cytotoxicity (ADCC) may be playing an important role, because this antibody isotype is the best at engaging this process. ${ }^{44,45}$ Interestingly, IgG3 responses were significantly lower in Vaxgen compared with the RV144 study. ${ }^{44}$ The tremendous numbers of interrelated correlative findings support the validity of the partial efficacy seen in the RV144 Study.

Although the protection afforded in the RV144 study was modest, mathematical modeling studies have demonstrated that this vaccine regimen could be quite effective in reducing the number of new infections in select regions. ${ }^{46,47}$ However, these assumptions are only valid if the vaccine regimen tested in RV144 truly prevents HIV infection. Therefore, confirmatory studies are planned using a similar vaccine regimen in both Thailand and Southern Africa. Furthermore, additional vaccine efficacy studies are planned in Southern Africa with other regimens that appear highly immunogenic in early clinical trials with the hopes of improving efficacy rates.

\section{IMPROVEMENTS TO VACCINE-ELICITED IMMUNE RESPONSES}

\section{Antibodies}

Antibodies able to directly neutralize virus are generally thought to be the best predictor of vaccine efficacy, and this immune response has correlated well with vaccine-induced 
protection for diseases such as polio, hepatitis B, and measles. ${ }^{48}$ However, other effective vaccines largely induce nonneutralizing antibodies that are likely protecting through their functional attributes. ${ }^{49}$ The latter likely occurs from antibodies able to bind to the pathogen via their variable domain. The Fc portion of the antibody-bound pathogen is then more efficiently recognized by immune cells through the Fc receptor. Depending on the type of the cell engaged, several processes are initiated, such as phagocytosis, complementmediated cellular lysis, and ADCC, all resulting in pathogen clearance. ${ }^{50-56}$ The latter function is especially interesting to the vaccine field going forward in light of the correlation with protection seen in the RV144 Study. ${ }^{50}$ By modulating the vector, enveloping the antigen, and coadministering with a variety of adjuvants, numerous groups are hoping to enhance the functional antibody responses to improve the next generation of HIV vaccine regimens.

It was also intriguing that the vaccine regimen used in the RV144 Study provided up to $60 \%$ efficacy at 1 year following the final immunization, but this effectiveness rapidly declined in conjunction with antibody responses. ${ }^{45,57-59}$ It is possible, therefore, that inducing a greater magnitude of antibody responses alone will significantly improve the observed vaccine efficacy. To this end, studies are underway to evaluate vaccine regimens designed to provide a better prime and enhanced boost to the immune response. This improvement will be evaluated with a combination of different adjuvants, vectors with enhanced delivery profiles, envelopes with better antigenic properties, and more frequent boosting, all in an attempt to increase the magnitude of the vaccine-induced antibody responses. Additional strategies to increase the durability of these responses also need to be explored.

Antibodies able to neutralize HIV by itself are rightfully understood to be the ideal vaccineinduced immune response. ${ }^{60}$ Neutralizing antibodies are not only able to eliminate cell-free virus, they are also able to work in a coordinated fashion with other components of the immune system to combat infected cells. However, such antibodies have been extremely difficult to elicit with any HIV vaccine tested to date, inducing a response that is able to eliminate even a fraction of the easiest to neutralize viruses. ${ }^{61}$ The reasons for these difficulties are many, including the vast diversity of HIV, whereby even antibodies able to neutralize a single viral clone are unable to do so for other highly related but genetically distinct viruses in the patient's quasispecies. ${ }^{62,63}$ Such type-specific antibody immunity is not unusual and is in fact the predominant type of response that is seen for almost all commercially developed vaccines. For example, the human papilloma virus vaccine induces antibodies that are highly effective in protecting against the types of viruses included in the vaccine but can also cross-protect against ongogenic nonvaccine types that are not encoded by this immunogen. ${ }^{64-66}$ Such a strategy works well when only a few viral subtypes cause significant disease (eg, $75 \%$ of cervical cancers are caused by HPV types 16 or 18); however, for HIV, virtually every functional virus is able to cause AIDS, and there are thousands of different HIV viral strains circulating in the human population. ${ }^{67}$ If such viral diversity itself were not daunting enough, it is generally difficult to induce HIV neutralizing antibodies even with conventional vaccines. High-affinity antibodies generally require antibody maturation provided in large part by somatic mutations that evolve over time following exposure to the virus. For HIV, most potent neutralizing antibodies require extensive somatic hypermutation and are rarely induced before the first year following 
infection. ${ }^{68-72}$ Many neutralizing antibody characteristics, such as a long CDR3 region, are also uncommon in humans and very difficult to induce in mice, which are historically used as the preclinical model of vaccine development. ${ }^{73}$

Despite these difficulties, neutralizing antibodies are elicited in most HIV-infected individuals. ${ }^{74,75}$ Furthermore, antibodies derived from a subset of individuals are able to neutralize a broad range of viruses. ${ }^{68}$ In fact, over the past several years, a great number of potent, broadly neutralizing monoclonal antibodies have been developed because of the development of novel technological advances. ${ }^{76,77}$ Envelope antibodies were used as "baits" to identify B cells by flow cytometry, which are then sorted and examined genetically to reconstruct antibodies. These monoclonal antibodies are then screened for their ability to neutralize virus, and many have been found to have broad potency. The ability to solve the structure of envelope in combination with these broadly neutralizing antibodies has led to important insights into what may be needed to induce such responses with a vaccine. ${ }^{78,79}$ Several groups are attempting to use "reverse vaccinology" to improve the antibody response. ${ }^{80-82}$ This technique involves identifying a broadly neutralizing monoclonal antibody and then screening reactivity of this antibody against several envelope antigens. ${ }^{83}$ Antigens with the highest reactivity would then be used as vaccines to determine whether they are able to induce the desired antibody response. This strategy may have to be combined with sequential vaccination, possibly with different forms of the envelope antigen to induce the antibody somatic hypermutation that appears to be required for generating broadly neutralizing antibody responses. Although these techniques are extremely complicated and not previously used in vaccine development, they are beginning to yield a set of blueprints from which it is hoped that more informed envelope antigen design can take place.

\section{T Cells}

It was understood early in HIV vaccine development that inducing antibodies of sufficient breadth to combat the diversity of HIV would be problematic. ${ }^{84-86}$ Furthermore, it was very difficult to induce antibodies that were able to neutralize primary HIV isolates or those implicated in most acute infections. These concerns were enhanced with the findings that the AIDSVAX bivalent gp120 vaccine was unable to protect against infection in 2 separate trials. $^{21,23}$ At the same time, investigators noted that CD8 T-cell responses were able to kill HIV-infected cells with a much greater breadth than observed for antibodies. ${ }^{87-91}$ CD8 T cells were also able to kill cells infected with primary HIV isolates. This renewed optimism led to the development of several vaccines whose primary goal was to induce T-cell responses. Preclinical data with these vaccine regimens looked very promising; however, protection against infection was generally not observed. ${ }^{32,92,93}$ Rather, most of these vaccines protected against disease progression in vaccinated macaques and even this protection depended on the simian immunodeficiency virus (SIV) strain used for challenge. ${ }^{94}$ Despite this optimism, 2 clinical studies have induced CD8 T-cell responses as the main response (Step Study) or in conjunction with antibody responses (HVTN 505), yet both studies failed to protect against infection or clinical markers of disease progression. ${ }^{22,24}$ For the former study, eliciting CD8 T cells capable of preventing infection or impacting set-point viral load was one of the major endpoints. ${ }^{22}$ Despite eliciting a high 
frequency and magnitude of response, this vaccine failed. One of the reasons for this is thought to be a narrow breadth of response. ${ }^{95}$ Therefore, strategies that can enhance the breadth of CD8 T-cell responses are desirable for improving vaccine design. Despite the overall failure of this regimen, it is interesting to note that in vaccinees endowed with protective HLA-I alleles, Gag-specific responses correlated with a lower set point viral load. ${ }^{96}$ The immune analyses for HVTN505 are ongoing.

Based on the above data, the field has serious doubts that a vaccine inducing CD8 T-cell responses as its primary immune response will ever be useful for an HIV vaccine; however, there is a wealth of information from both animal models and human data that these cells are essential for HIV viral control. ${ }^{97-102}$ Even under the best of circumstances, antibodies are unlikely to protect against every infection and CD8 T cells will likely be needed for improved control following these infections. Furthermore, emerging data with what seems to be appropriate SIV challenge virus suggest that vaccine-induced CD8 T-cell responses are able to rapidly control infection to the extent that it is no longer detected in the challenged animals. ${ }^{97,103-105}$ Although these data have used an unusual rhesus macaque cytomegalovirus vector, a more recent study was able to demonstrate protection against infection with a more conventional vectored approach that induced high levels of mucosal CD8 T-cell responses (David Masapoust, unpublished data, 2014). Such preclinical data point to an important role for CD8 T-cell responses to be included as part of a preventative vaccine in combination with reactive CD4 T cells and broadly reactive antibody responses, be it binding and/or neutralizing. As such, there is a renewed interest in developing vaccine regimens able to induce CD8 T-cell response of increased magnitude and breadth, especially those that are able to traffic to mucosal sites.

CD4 T-cell responses have received relatively little attention in terms of vaccine design, in part due to the fact the these cells are the primary targets of HIV infection and the arguable logic that enhancing these responses will inevitably fuel infection. However, there are preclinical data to suggest that HIV-specific CD4 T cells may be playing a contributing role in disease protection. ${ }^{106}$ Furthermore, the RV144 correlates studies implicated CD4 T cells as playing at least a contributing role in protection against infection. ${ }^{58}$ Although the exact mechanism behind this correlate of protection remains unknown, it is certainly plausible that CD4 T cells were enhancing the vaccine-induced antibody responses. In addition to its helper functions, CD4 T cells have long been known to possess lytic function; this characteristic was recently found to predict enhanced viral control when evaluated shortly after acute infection ${ }^{107}$ and was also observed in RV144. ${ }^{108}$ For these reasons, it seems prudent that future vaccine designs consider optimizing the induction and evaluation of CD4 T cells in addition to CD8 T cells. ${ }^{109}$

\section{SUMMARY}

HIV vaccine development began shortly after the discovery of this pathogen as the cause of AIDS. ${ }^{110}$ Despite more than 25 years into the HIV epidemic, and the numerous preclinical and clinical testing of vaccines, only 4 regimens have reached efficacy stage testing to evaluate their ability to prevent HIV infection or disease progression. Only 1 of these 4 vaccine regimens was found to induce modest protection against infection but none 
demonstrated improved clinical markers of disease progression (lower set-point viral load and maintained CD4 T-cell counts) in those infected despite vaccination. ${ }^{25}$ Nevertheless, a wealth of information was obtained from all of the efficacy trials, enhancing the understanding of the impact of vaccination on viral evolution and disease transmission. ${ }^{111}$ For RV144, in particular, clear immune correlates of protection against HIV infection have been obtained; however, it is important to first confirm that the RV144 results are reproducible in subsequent trials in light of the modest rate of efficacy that just reached statistical significance. Fortunately, 2 studies are planned for near future (one in Thailand and one in Southern Africa), which will attempt to confirm the efficacy of the ALVAC/ gp120 vaccine regimen. ${ }^{112,113}$ These studies will determine whether the same correlates of HIV infection are seen as in the RV144 study, thereby potentially yielding valuable information to be used for more directed improvements in vaccine design.

It is important for the HIV vaccine field to continue to develop new products and move them rapidly to clinical testing. ${ }^{111,114}$ Investigators should not be dissuaded by products that are significantly different than the RV144 regimen, as long as the scientific rationale is sound. This statement is especially pertinent in a field that has been fraught with focusing too heavily on a single vaccine platform without a developed backup plan when the former is found to be inefficacious. More importantly, a pertinent goal for the HIV vaccine field in the future is to increase the number of products tested concurrently for clinical efficacy. Sadly, this bar is not high enough, considering only 4 products have been tested for efficacy in more than 25 years of vaccine development. In general, vaccine development is an iterative process with more failures than successes, and significantly increasing the number of attempts is essential to developing a safe and effective HIV vaccine.

\section{Acknowledgments}

We thank Victor Du for his help with the graphics.

\section{References}

1. CDC. [Accessed May 6, 2014] HIV incidence: centers for disease control. 2010. Available at: http:// www.cdc.gov/hiv/statistics/surveillance/incidence/

2. WHO. Global summary of the AIDS epidemic. World Health Organization; 2012. [cited May 6, 2014]. Available at: http://www.who.int/hiv/data/en/

3. Vermund SH, Tique JA, Cassell HM, et al. Translation of biomedical prevention strategies for HIV: prospects and pitfalls. J Acquir Immune Defic Syndr. 2013; 63(Suppl 1):S12-25. http://dx.doi.org/ 10.1097/QAI.0b013e31829202a2. [PubMed: 23673881]

4. Auvert B, Taljaard D, Lagarde E, et al. Randomized, controlled intervention trial of male circumcision for reduction of HIV infection risk: the ANRS 1265 Trial. PLoS Med. 2005; 2(11):e298. http://dx.doi.org/10.1371/journal.pmed.0020298. [PubMed: 16231970]

5. Bailey RC, Moses S, Parker CB, et al. Male circumcision for HIV prevention in young men in Kisumu, Kenya: a randomised controlled trial. Lancet. 2007; 369(9562):643-56. http://dx.doi.org/ 10.1016/S0140-6736(07)60312-2. [PubMed: 17321310]

6. Gray RH, Kigozi G, Serwadda D, et al. Male circumcision for HIV prevention in men in Rakai, Uganda: a randomised trial. Lancet. 2007; 369(9562):657-66. http://dx.doi.org/10.1016/ S0140-6736(07)60313-4. [PubMed: 17321311] 
7. Baeten JM, Donnell D, Ndase P, et al. Partners PrEP Study Team. Antiretroviral prophylaxis for HIV prevention in heterosexual men and women. N Engl J Med. 2012; 367(5):399-410. http:// dx.doi.org/10.1056/NEJMoa1108524. [PubMed: 22784037]

8. Grant RM, Lama JR, Anderson PL, et al. iPrEx Study Team. Preexposure chemoprophylaxis for HIV prevention in men who have sex with men. N Engl J Med. 2010; 363(27):2587-99. http:// dx.doi.org/10.1056/NEJMoa1011205. [PubMed: 21091279]

9. Thigpen MC, Kebaabetswe PM, Paxton LA, et al. TDF2 Study Group. Antiretroviral preexposure prophylaxis for heterosexual HIV transmission in Botswana. N Engl J Med. 2012; 367(5):423-34. http://dx.doi.org/10.1056/NEJMoa1110711. [PubMed: 22784038]

10. Cohen MS, Chen YQ, McCauley M, et al. Prevention of HIV-1 infection with early antiretroviral therapy. N Engl J Med. 2011; 365(6):493-505. http://dx.doi.org/10.1056/NEJMoa1105243. [PubMed: 21767103]

11. Couch RB. Seasonal inactivated influenza virus vaccines. Vaccine. 2008; 26(Suppl 4):D5-9. http:// dx.doi.org/10.1016/j.vaccine.2008.05.076. [PubMed: 18602728]

12. Salk JE. Recent studies on immunization against poliomyelitis. Pediatrics. 1953; 12(5):471-82. [PubMed: 13111847]

13. Salk JE. Principles of immunization as applied to poliomyelitis and influenza. Am J Public Health Nations Health. 1953; 43(11):1384-98. [PubMed: 13104698]

14. Kennedy RB, Ovsyannikova IG, Jacobson RM, et al. The immunology of smallpox vaccines. Curr Opin Immunol. 2009; 21(3):314-20. http://dx.doi.org/10.1016/j.coi.2009.04.004. [PubMed: 19524427]

15. Benmira S, Bhattacharya V, Schmid ML. An effective HIV vaccine: a combination of humoral and cellular immunity? Curr HIV Res. 2010; 8(6):441-9. [PubMed: 20636279]

16. Letvin NL. Progress and obstacles in the development of an AIDS vaccine. Nat Rev Immunol. 2006; 6(12):930-9. http://dx.doi.org/10.1038/nri1959. [PubMed: 17124514]

17. Kim JH, Rerks-Ngarm S, Excler JL, et al. HIV vaccines: lessons learned and the way forward. Curr Opin HIV AIDS. 2010; 5(5):428-34. http://dx.doi.org/10.1097/COH.0b013e32833d17ac. [PubMed: 20978385]

18. Johnson JA, Barouch DH, Baden LR. Nonreplicating vectors in HIV vaccines. Curr Opin HIV AIDS. 2013; 8(5):412-20. http://dx.doi.org/10.1097/COH.0b013e328363d3b7. [PubMed: 23925001]

19. Churchyard GJ, Morgan C, Adams E, et al. Network NHVT. A phase IIA randomized clinical trial of a multiclade HIV-1 DNA prime followed by a multiclade rAd5 HIV-1 vaccine boost in healthy adults (HVTN204). PLoS One. 2011; 6(8):e21225. http://dx.doi.org/10.1371/journal.pone. 0021225. [PubMed: 21857901]

20. Goepfert PA, Horton H, McElrath MJ, et al. Network NHVT. High-dose recombinant Canarypox vaccine expressing HIV-1 protein, in seronegative human subjects. J Infect Dis. 2005; 192(7): 1249-59. http://dx.doi.org/10.1086/432915. [PubMed: 16136469]

21. Pitisuttithum P, Gilbert P, Gurwith M, et al. Bangkok Vaccine Evaluation Group. Randomized, double-blind, placebo-controlled efficacy trial of a bivalent recombinant glycoprotein $120 \mathrm{HIV}-1$ vaccine among injection drug users in Bangkok, Thailand. J Infect Dis. 2006; 194(12):1661-71. http://dx.doi.org/10.1086/508748. [PubMed: 17109337]

22. Buchbinder SP, Mehrotra DV, Duerr A, et al. Step Study Protocol Team. Efficacy assessment of a cell-mediated immunity HIV-1 vaccine (the Step Study): a double-blind, randomised, placebocontrolled, test-of-concept trial. Lancet. 2008; 372(9653):1881-93. http://dx.doi.org/10.1016/ S0140-6736(08)61591-3. [PubMed: 19012954]

23. Flynn NM, Forthal DN, Harro CD, et al. rgp HIV Vaccine Study Group. Placebo-controlled phase 3 trial of a recombinant glycoprotein 120 vaccine to prevent HIV-1 infection. J Infect Dis. 2005; 191(5):654-65. http://dx.doi.org/10.1086/428404. [PubMed: 15688278]

24. Hammer SM, Sobieszczyk ME, Janes H, et al. Efficacy trial of a DNA/rAd5 HIV-1 preventive vaccine. N Engl J Med. 2013; 369(22):2083-92. http://dx.doi.org/10.1056/NEJMoa1310566. [PubMed: 24099601] 
25. Rerks-Ngarm S, Pitisuttithum P, Nitayaphan S, et al. MOPH-TAVEG Investigators. Vaccination with ALVAC and AIDSVAX to prevent HIV-1 infection in Thailand. N Engl J Med. 2009; 361(23):2209-20. http://dx.doi.org/10.1056/NEJMoa0908492. [PubMed: 19843557]

26. Billich A. AIDSVAX VaxGen. Curr Opin Investig Drugs. 2004; 5(2):214-21.

27. Pitisuttithum P, Berman PW, Phonrat B, et al. Phase I/II study of a candidate vaccine designed against the B and E subtypes of HIV-1. J Acquir Immune Defic Syndr. 2004; 37(1):1160-5. [PubMed: 15319676]

28. Vanichseni S, Tappero JW, Pitisuttithum P, et al. Bangkok Vaccine Evaluation Group. Recruitment, screening and characteristics of injection drug users participating in the AIDSVAX B/E HIV vaccine trial, Bangkok, Thailand. AIDS. 2004; 18(2):311-6. [PubMed: 15075550]

29. Floreani A, Baldo V, Cristofoletti M, et al. Long-term persistence of anti-HBs after vaccination against HBV: an 18 year experience in health care workers. Vaccine. 2004; 22(5-6):607-10. [PubMed: 14741151]

30. Keating GM, Noble S. Recombinant hepatitis B vaccine (Engerix-B): a review of its immunogenicity and protective efficacy against hepatitis B. Drugs. 2003; 63(10):1021-51. [PubMed: 12699402]

31. Poland GA, Jacobson RM. Clinical practice: prevention of hepatitis B with the hepatitis B vaccine. N Engl J Med. 2004; 351(27):2832-8. http://dx.doi.org/10.1056/NEJMcp041507. [PubMed: 15625334]

32. Shiver JW, Fu TM, Chen L, et al. Replication-incompetent adenoviral vaccine vector elicits effective anti-immunodeficiency-virus immunity. Nature. 2002; 415(6869):331-5. http:// dx.doi.org/10.1038/415331a. [PubMed: 11797011]

33. Duerr A, Huang Y, Buchbinder S, et al. Extended follow-up confirms early vaccine-enhanced risk of HIV acquisition and demonstrates waning effect over time among participants in a randomized trial of recombinant adenovirus HIV vaccine (Step Study). J Infect Dis. 2012; 206(2):258-66. http://dx.doi.org/10.1093/infdis/jis342. [PubMed: 22561365]

34. Volk JE, Hessol NA, Gray GE, et al. The HVTN503/Phambili HIV vaccine trial: a comparison of younger and older participants. Int J STD AIDS. 2014; 25(5):332-40. http://dx.doi.org/ 10.1177/0956462413506892. [PubMed: 24104693]

35. Catanzaro AT, Koup RA, Roederer M, et al. Vaccine Research Center 006 Study Team. Phase 1 safety and immunogenicity evaluation of a multiclade HIV-1 candidate vaccine delivered by a replication-defective recombinant adenovirus vector. J Infect Dis. 2006; 194(12):1638-49. http:// dx.doi.org/10.1086/509258. [PubMed: 17109335]

36. Belshe RB, Stevens C, Gorse GJ, et al. National Institute of Allergy and Infectious Diseases AIDS Vaccine Evaluation Group and HIV Network for Prevention Trials(HIVNET). Safety and immunogenicity of a canarypox-vectored human immunodeficiency virus type 1 vaccine with or without gp120: a phase 2 study in higher- and lower-risk volunteers. J Infect Dis. 2001; 183(9): 1343-52. http://dx.doi.org/10.1086/319863. [PubMed: 11294665]

37. Russell ND, Graham BS, Keefer MC, et al. National Institute of Allergy and Infectious Diseases HIV Vaccine Trials Network. Phase 2 study of an HIV-1 canarypox vaccine (vCP1452) alone and in combination with rgp120: negative results fail to trigger a phase 3 correlates trial. J Acquir Immune Defic Syndr. 2007; 44(2):203-12. http://dx.doi.org/10.1097/01.qai.0000248356.48501.ff. [PubMed: 17106277]

38. Burton DR, Desrosiers RC, Doms RW, et al. Public health. A sound rationale needed for phase III HIV-1 vaccine trials. Science. 2004; 303(5656):316. http://dx.doi.org/10.1126/science.1094620. [PubMed: 14726576]

39. Alam SM, Liao HX, Tomaras GD, et al. Antigenicity and immunogenicity of RV144 vaccine AIDSVAX clade E envelope immunogen is enhanced by a gp120 N-terminal deletion. J Virol. 2013; 87(3):1554-68. http://dx.doi.org/10.1128/JVI.00718-12. [PubMed: 23175357]

40. Robb ML, Rerks-Ngarm S, Nitayaphan S, et al. Risk behaviour and time as covariates for efficacy of the HIV vaccine regimen ALVAC-HIV (vCP1521) and AIDSVAX B/E: a post-hoc analysis of the Thai phase 3 efficacy trial RV 144. Lancet Infect Dis. 2012; 12(7):531-7. http://dx.doi.org/ 10.1016/S1473-3099(12)70088-9. [PubMed: 22652344] 
41. Zolla-Pazner S, deCamp A, Gilbert PB, et al. Vaccine-induced IgG antibodies to V1V2 regions of multiple HIV-1 subtypes correlate with decreased risk of HIV-1 infection. PLoS One. 2014; 9(2):e87572. http://dx.doi.org/10.1371/journal.pone.0087572. [PubMed: 24504509]

42. Tomaras GD, Ferrari G, Shen X, et al. Vaccine-induced plasma IgA specific for the C1 region of the HIV-1 envelope blocks binding and effector function of IgG. Proc Natl Acad Sci U S A. 2013; 110(22):9019-24. http://dx.doi.org/10.1073/pnas.1301456110. [PubMed: 23661056]

43. Rolland M, Edlefsen PT, Larsen BB, et al. Increased HIV-1 vaccine efficacy against viruses with genetic signatures in Env V2. Nature. 2012; 490(7420):417-20. http://dx.doi.org/10.1038/ nature11519. [PubMed: 22960785]

44. Chung AW, Ghebremichael M, Robinson H, et al. Polyfunctional Fc-effector profiles mediated by IgG subclass selection distinguish RV144 and VAX003 vaccines. Sci Transl Med. 2014; 6(228): 228ra38. http://dx.doi.org/10.1126/scitranslmed.3007736.

45. Yates NL, Liao HX, Fong Y, et al. Vaccine-induced Env V1-V2 IgG3 correlates with lower HIV-1 infection risk and declines soon after vaccination. Sci Transl Med. 2014; 6(228):228ra39. http:// dx.doi.org/10.1126/scitranslmed.3007730.

46. Hontelez JA, Nagelkerke N, Barnighausen T, et al. The potential impact of RV144-like vaccines in rural South Africa: a study using the STDSIM microsimulation model. Vaccine. 2011; 29(36): 6100-6. http://dx.doi.org/10.1016/j.vaccine.2011.06.059. [PubMed: 21703321]

47. Nagelkerke NJ, Hontelez JA, de Vlas SJ. The potential impact of an HIV vaccine with limited protection on HIV incidence in Thailand: a modeling study. Vaccine. 2011; 29(36):6079-85. http://dx.doi.org/10.1016/j.vaccine.2011.06.048. [PubMed: 21718745]

48. Thakur A, Pedersen LE, Jungersen G. Immune markers and correlates of protection for vaccine induced immune responses. Vaccine. 2012; 30(33):4907-20. http://dx.doi.org/10.1016/j.vaccine. 2012.05.049. [PubMed: 22658928]

49. Forthal D, Hope TJ, Alter G. New paradigms for functional HIV-specific non-neutralizing antibodies. Curr Opin HIV AIDS. 2013; 8(5):393-401. http://dx.doi.org/10.1097/COH. 0b013e328363d486. [PubMed: 23924999]

50. Bonsignori M, Pollara J, Moody MA, et al. Antibody-dependent cellular cytotoxicity-mediating antibodies from an HIV-1 vaccine efficacy trial target multiple epitopes and preferentially use the VH1 gene family. J Virol. 2012; 86(21):11521-32. http://dx.doi.org/10.1128/JVI.01023-12. [PubMed: 22896626]

51. Chung AW, Navis M, Isitman G, et al. Activation of NK cells by ADCC antibodies and HIV disease progression. J Acquir Immune Defic Syndr. 2011; 58(2):127-31. http://dx.doi.org/ 10.1097/QAI.0b013e31822c62b9. [PubMed: 21792067]

52. Huber G, Banki Z, Lengauer S, et al. Emerging role for complement in HIV infection. Curr Opin HIV AIDS. 2011; 6(5):419-26. http://dx.doi.org/10.1097/COH.0b013e3283495a26. [PubMed: 21825871]

53. Isitman G, Stratov I, Kent SJ. Antibody-dependent cellular cytotoxicity and NK cell-driven immune escape in HIV infection: implications for HIV vaccine development. Adv Virol. 2012; 2012:637208. http://dx.doi.org/10.1155/2012/637208. [PubMed: 22611395]

54. Mazzolini J, Herit F, Bouchet J, et al. Inhibition of phagocytosis in HIV-1-infected macrophages relies on Nef-dependent alteration of focal delivery of recycling compartments. Blood. 2010; 115(21):4226-36. http://dx.doi.org/10.1182/blood-2009-12-259473. [PubMed: 20299515]

55. Torre D, Gennero L, Baccino FM, et al. Impaired macrophage phagocytosis of apoptotic neutrophils in patients with human immunodeficiency virus type 1 infection. Clin Diagn Lab Immunol. 2002; 9(5):983-6. [PubMed: 12204947]

56. Wren L, Parsons MS, Isitman G, et al. Influence of cytokines on HIV-specific antibody-dependent cellular cytotoxicity activation profile of natural killer cells. PLoS One. 2012; 7(6):e38580. http:// dx.doi.org/10.1371/journal.pone.0038580. [PubMed: 22701674]

57. Zolla-Pazner S, deCamp AC, Cardozo T, et al. Analysis of V2 antibody responses induced in vaccinees in the ALVAC/AIDSVAX HIV-1 vaccine efficacy trial. PLoS One. 2013; 8(1):e53629. http://dx.doi.org/10.1371/journal.pone.0053629. [PubMed: 23349725] 
58. Haynes BF, Gilbert PB, McElrath MJ, et al. Immune-correlates analysis of an HIV-1 vaccine efficacy trial. N Engl J Med. 2012; 366(14):1275-86. http://dx.doi.org/10.1056/NEJMoa1113425. [PubMed: 22475592]

59. Montefiori DC, Karnasuta C, Huang Y, et al. Magnitude and breadth of the neutralizing antibody response in the RV144 and Vax003 HIV-1 vaccine efficacy trials. J Infect Dis. 2012; 206(3):43141. http://dx.doi.org/10.1093/infdis/jis367. [PubMed: 22634875]

60. Mascola JR, Haynes BF. HIV-1 neutralizing antibodies: understanding nature's pathways. Immunol Rev. 2013; 254(1):225-44. http://dx.doi.org/10.1111/imr.12075. [PubMed: 23772623]

61. Montefiori DC, Mascola JR. Neutralizing antibodies against HIV-1: can we elicit them with vaccines and how much do we need? Curr Opin HIV AIDS. 2009; 4(5):347-51. http://dx.doi.org/ 10.1097/COH.0b013e32832f4a4d. [PubMed: 20048696]

62. Basu D, Kraft CS, Murphy MK, et al. HIV-1 subtype C superinfected individuals mount low autologous neutralizing antibody responses prior to intrasubtype superinfection. Retrovirology. 2012; 9:76. http://dx.doi.org/10.1186/1742-4690-9-76. [PubMed: 22995123]

63. Smith TL, van Rensburg EJ, Engelbrecht S. Neutralization of HIV-1 subtypes: implications for vaccine formulations. J Med Virol. 1998; 56(3):264-8. [PubMed: 9783696]

64. Toft L, Tolstrup M, Muller M, et al. Comparison of the immunogenicity of Cervarix and Gardasil human papillomavirus vaccines for oncogenic non-vaccine sero-types HPV-31, HPV-33, and HPV-45 in HIV-infected adults. Hum Vaccin Immunother. 2014; 10(5)

65. Einstein MH, Baron M, Levin MJ, et al. Comparison of the immunogenicity and safety of Cervarix and Gardasil human papillomavirus (HPV) cervical cancer vaccines in healthy women aged 18-45 years. Hum Vaccin. 2009; 5(10):705-19. [PubMed: 19684472]

66. Einstein MH, Baron M, Levin MJ, et al. Comparison of the immunogenicity of the human papillomavirus (HPV)-16/18 vaccine and the HPV-6/11/16/18 vaccine for oncogenic non-vaccine types HPV-31 and HPV-45 in healthy women aged 18-45 years. Hum Vaccin. 2011; 7(12):135973. http://dx.doi.org/10.4161/hv.7.12.18282. [PubMed: 22048172]

67. Gaschen B, Taylor J, Yusim K, et al. Diversity considerations in HIV-1 vaccine selection. Science. 2002; 296(5577):2354-60. http://dx.doi.org/10.1126/science.1070441. [PubMed: 12089434]

68. Hraber P, Seaman MS, Bailer RT, et al. Prevalence of broadly neutralizing antibody responses during chronic HIV-1 infection. AIDS. 2014; 28(2):163-9. http://dx.doi.org/10.1097/QAD. 0000000000000106. [PubMed: 24361678]

69. Klein F, Diskin R, Scheid JF, et al. Somatic mutations of the immunoglobulin framework are generally required for broad and potent HIV-1 neutralization. Cell. 2013; 153(1):126-38. http:// dx.doi.org/10.1016/j.cell.2013.03.018. [PubMed: 23540694]

70. Medina-Ramirez M, Sanders RW, Klasse PJ. Targeting B-cell germlines and focusing affinity maturation: the next hurdles in HIV-1-vaccine development? Expert RevVaccines. 2014; 13(4): 449-52. http://dx.doi.org/10.1586/14760584.2014.894469.

71. Doria-Rose, NA.; Schramm, CA.; Gorman, J., et al. Developmental pathway for potent V1V2directed HIV-neutralizing antibodies. Nature. 2014. http://dx.doi.org/10.1038/nature13036

72. Liao HX, Lynch R, Zhou T, et al. Co-evolution of a broadly neutralizing HIV-1 antibody and founder virus. Nature. 2013; 496(7446):469-76. http://dx.doi.org/10.1038/nature12053. [PubMed: 23552890]

73. West AP Jr, Scharf L, Scheid JF, et al. Structural insights on the role of antibodies in HIV-1 vaccine and therapy. Cell. 2014; 156(4):633-48. http://dx.doi.org/10.1016/j.cell.2014.01.052. [PubMed: 24529371]

74. Richman DD, Wrin T, Little SJ, et al. Rapid evolution of the neutralizing antibody response to HIV type 1 infection. Proc Natl Acad Sci U S A. 2003; 100(7):4144-9. http://dx.doi.org/10.1073/pnas. 0630530100. [PubMed: 12644702]

75. Wei X, Decker JM, Wang S, et al. Antibody neutralization and escape by HIV-1. Nature. 2003; 422(6929):307-12. http://dx.doi.org/10.1038/nature01470. [PubMed: 12646921]

76. Scheid JF, Mouquet H, Feldhahn N, et al. Broad diversity of neutralizing antibodies isolated from memory B cells in HIV-infected individuals. Nature. 2009; 458(7238):636-40. http://dx.doi.org/ 10.1038/nature07930. [PubMed: 19287373] 
77. Moody MA, Yates NL, Amos JD, et al. HIV-1 gp120 vaccine induces affinity maturation in both new and persistent antibody clonal lineages. J Virol. 2012; 86(14):7496-507. http://dx.doi.org/ 10.1128/JVI.00426-12. [PubMed: 22553329]

78. Huang J, Ofek G, Laub L, et al. Broad and potent neutralization of HIV-1 by a gp41-specific human antibody. Nature. 2012; 491(7424):406-12. http://dx.doi.org/10.1038/nature11544. [PubMed: 23151583]

79. McLellan JS, Pancera M, Carrico C, et al. Structure of HIV-1 gp120 V1/V2 domain with broadly neutralizing antibody PG9. Nature. 2011; 480(7377):336-43. http://dx.doi.org/10.1038/ nature10696. [PubMed: 22113616]

80. Burton DR, Ahmed R, Barouch DH, et al. A blueprint for HIV vaccine discovery. Cell Host Microbe. 2012; 12(4):396-407. http://dx.doi.org/10.1016/j.chom.2012.09.008. [PubMed: 23084910]

81. Schief WR, Ban YE, Stamatatos L. Challenges for structure-based HIV vaccine design. Curr Opin HIV AIDS. 2009; 4(5):431-40. http://dx.doi.org/10.1097/COH.0b013e32832e6184. [PubMed: 20048708]

82. Stamatatos LHIV. vaccine design: the neutralizing antibody conundrum. Curr Opin Immunol. 2012; 24(3):316-23. http://dx.doi.org/10.1016/j.coi.2012.04.006. [PubMed: 22595693]

83. Ahlers JD. All eyes on the next generation of HIV vaccines: strategies for inducing a broadly neutralizing antibody response. Discov Med. 2014; 17(94):187-99. [PubMed: 24759623]

84. Daar ES, Li XL, Moudgil T, et al. High concentrations of recombinant soluble CD4 are required to neutralize primary human immunodeficiency virus type 1 isolates. Proc Natl Acad Sci U S A. 1990; 87(17):6574-8. [PubMed: 2395859]

85. Golding H, D'Souza MP, Bradac J, et al. Neutralization of HIV-1. AIDS Res Hum Retroviruses. 1994; 10(6):633-43. [PubMed: 8074927]

86. Moore JP, Cao Y, Qing L, et al. Primary isolates of human immunodeficiency virus type 1 are relatively resistant to neutralization by monoclonal antibodies to gp120, and their neutralization is not predicted by studies with monomeric gp120. J Virol. 1995; 69(1):101-9. [PubMed: 7527081]

87. Betts MR, Krowka J, Santamaria C, et al. Cross-clade human immunodeficiency virus (HIV)specific cytotoxic T-lymphocyte responses in HIV-infected Zambians. J Virol. 1997; 71(11):890811. [PubMed: 9343257]

88. Buseyne F, Chaix ML, Fleury B, et al. Cross-clade-specific cytotoxic T lymphocytes in HIV-1infected children. Virology. 1998; 250(2):316-24. http://dx.doi.org/10.1006/viro.1998.9373. [PubMed: 9792842]

89. Ferrari G, Humphrey W, McElrath MJ, et al. Clade B-based HIV-1 vaccines elicit cross-clade cytotoxic T lymphocyte reactivities in uninfected volunteers. Proc Natl Acad Sci U S A. 1997; 94(4):1396-401. [PubMed: 9037064]

90. McAdam S, Kaleebu P, Krausa P, et al. Cross-clade recognition of p55 by cytotoxic T lymphocytes in HIV-1 infection. AIDS. 1998; 12(6):571-9. [PubMed: 9583596]

91. Wilson SE, Pedersen SL, Kunich JC, et al. Cross-clade envelope glycoprotein 160-specific CD8+ cytotoxic T lymphocyte responses in early HIV type 1 clade B infection. AIDS Res Hum Retroviruses. 1998; 14(11):925-37. [PubMed: 9686639]

92. Amara RR, Villinger F, Altman JD, et al. Control of a mucosal challenge and prevention of AIDS by a multiprotein DNA/MVA vaccine. Science. 2001; 292(5514):69-74. [PubMed: 11393868]

93. Barouch DH, Santra S, Schmitz JE, et al. Control of viremia and prevention of clinical AIDS in rhesus monkeys by cytokine-augmented DNA vaccination. Science. 2000; 290(5491):486-92. [PubMed: 11039923]

94. Friedrich TC, Watkins DI. The role of the SIV model in AIDS vaccine research. IAVI Rep. 2005; 9(2):1, 6-8. [PubMed: 16156073]

95. McElrath MJ, De Rosa SC, Moodie Z, et al. Step Study Protocol T. HIV-1 vaccine-induced immunity in the test-of-concept Step Study: a case-cohort analysis. Lancet. 2008; 372(9653): 1894-905. http://dx.doi.org/10.1016/S0140-6736(08)61592-5. [PubMed: 19012957]

96. Janes H, Friedrich DP, Krambrink A, et al. Vaccine-induced gag-specific T cells are associated with reduced viremia after HIV-1 infection. J Infect Dis. 2013; 208(8):1231-9. http://dx.doi.org/ 10.1093/infdis/jit322. [PubMed: 23878319] 
97. Hansen SG, Ford JC, Lewis MS, et al. Profound early control of highly pathogenic SIV by an effector memory T-cell vaccine. Nature. 2011; 473(7348):523-7. http://dx.doi.org/10.1038/ nature10003. [PubMed: 21562493]

98. Kuroda MJ, Schmitz JE, Charini WA, et al. Emergence of CTL coincides with clearance of virus during primary simian immunodeficiency virus infection in rhesus monkeys. J Immunol. 1999; 162(9):5127-33. [PubMed: 10227983]

99. Schmitz JE, Kuroda MJ, Santra S, et al. Control of viremia in simian immunodeficiency virus infection by CD8+ lymphocytes. Science. 1999; 283(5403):857-60. [PubMed: 9933172]

100. Perreau M, Levy Y, Pantaleo G. Immune response to HIV. Curr Opin HIV AIDS. 2013; 8(4): 333-40. http://dx.doi.org/10.1097/COH.0b013e328361faf4. [PubMed: 23743723]

101. Jessen H, Allen TM, Streeck H. How a single patient influenced HIV research-15-year follow-up. N Engl J Med. 2014; 370(7):682-3. http://dx.doi.org/10.1056/NEJMc1308413. [PubMed: 24521131]

102. Shasha D, Walker BD. Lessons to be learned from natural control of HIV - future directions, therapeutic, and preventive implications. Front Immunol. 2013; 4:162. http://dx.doi.org/10.3389/ fimmu.2013.00162. [PubMed: 23805139]

103. Hansen SG, Piatak M Jr, Ventura AB, et al. Immune clearance of highly pathogenic SIV infection. Nature. 2013; 502(7469):100-4. http://dx.doi.org/10.1038/nature12519. [PubMed: 24025770]

104. Hansen SG, Sacha JB, Hughes CM, et al. Cytomegalovirus vectors violate CD8+ T cell epitope recognition paradigms. Science. 2013; 340(6135):1237874. http://dx.doi.org/10.1126/science. 1237874. [PubMed: 23704576]

105. Hansen SG, Vieville C, Whizin N, et al. Effector memory Tcell responses are associated with protection of rhesus monkeys from mucosal simian immunodeficiency virus challenge. Nat Med. 2009; 15(3):293-9. http://dx.doi.org/10.1038/nm,1935. [PubMed: 19219024]

106. Hel Z, Nacsa J, Tryniszewska E, et al. Containment of simian immunodeficiency virus infection in vaccinated macaques: correlation with the magnitude of virus-specific pre- and postchallenge CD4+ and CD8+ T cell responses. J Immunol. 2002; 169(9):4778-87. [PubMed: 12391187]

107. Soghoian DZ, Jessen H, Flanders M, et al. HIV-specific cytolytic CD4 T cell responses during acute HIV infection predict disease outcome. Sci Transl Med. 2012; 4(123):123ra25. http:// dx.doi.org/10.1126/scitranslmed.3003165.

108. de Souza MS, Ratto-Kim S, Chuenarom W, et al. Ministry of Public Health-Thai AVEGC. The Thai phase III trial (RV144) vaccine regimen induces T cell responses that preferentially target epitopes within the V2 region of HIV-1 envelope. J Immunol. 2012; 188(10):5166-76. http:// dx.doi.org/10.4049/jimmunol.1102756. [PubMed: 22529301]

109. Streeck H, D'Souza MP, Littman DR, et al. Harnessing CD4(+) T cell responses in HIV vaccine development. Nat Med. 2013; 19(2):143-9. http://dx.doi.org/10.1038/nm.3054. [PubMed: 23389614]

110. Zagury D, Bernard J, Cheynier R, et al. A group specific anamnestic immune reaction against HIV-1 induced by a candidate vaccine against AIDS. Nature. 1988; 332(6166):728-31. http:// dx.doi.org/10.1038/332728a0. [PubMed: 3162762]

111. Bansal GP, Malaspina A, Flores J. Future paths for HIV vaccine research: Exploiting results from recent clinical trials and current scientific advances. Curr Opin Mol Ther. 2010; 12(1):39-46. [PubMed: 20140815]

112. Williamson AL, Rybiki E, Shephard E, et al. South African HIV-1 vaccine candidates - the journey from the bench to clinical trials. S Afr Med J. 2012; 102(6):452-5. [PubMed: 22668934]

113. Vaccari M, Poonam P, Franchini G. Phase III HIV vaccine trial in Thailand: a step toward a protective vaccine for HIV. Expert Rev Vaccines. 2010; 9(9):997-1005. http://dx.doi.org/ 10.1586/erv.10.104. [PubMed: 20822342]

114. Cohen YZ, Dolin R. Novel HIV vaccine strategies: overview and perspective. Ther Adv Vaccines. 2013; 1(3):99-112. http://dx.doi.org/10.1177/2051013613494535. [PubMed: 24757518] 


\section{KEY POINTS}

- The currently available clinical vaccines are based on inducing type-specific immunity, which is unlikely to work for a genetically diverse pathogen such as HIV.

- A recent HIV vaccine trial demonstrated $31 \%$ efficacy against HIV infection, but no protection against clinical markers of disease progression in those infected despite vaccination.

- The modest vaccine efficacy has led to the identification of new nonneutralizing (binding) antibodies that correlated with vaccine efficacy.

- Improvements to HIV-induced CD8 T-cell responses likely are needed if a vaccine is to change the clinical parameters of disease progression.

- Optimizing CD4 T-cell responses likely is essential to enhance the quality of antibodies and CD8 $\mathrm{T}$ cells. 


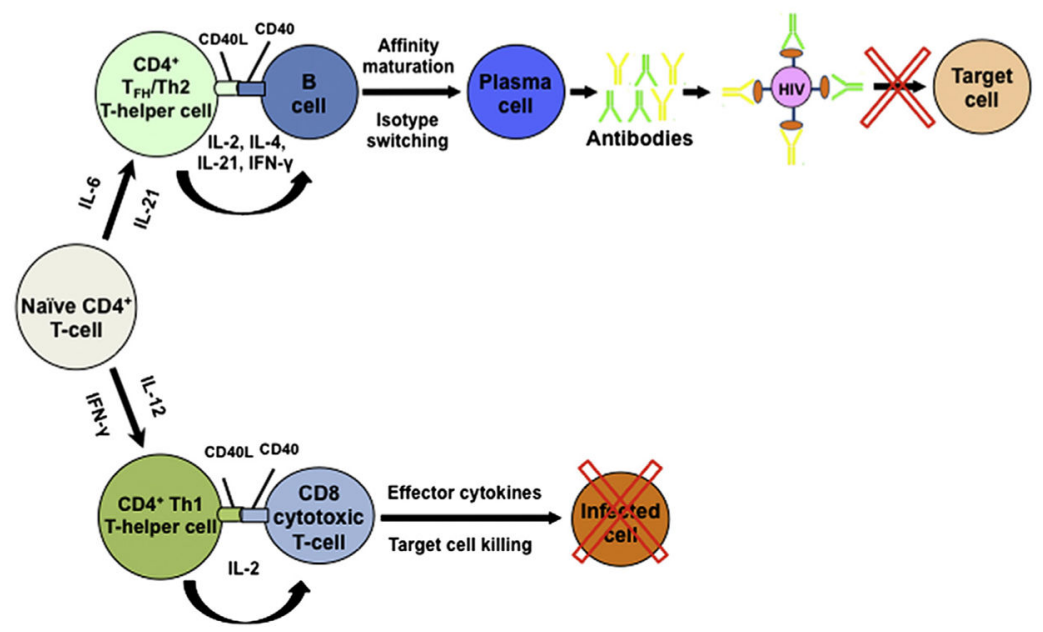

Fig. 1.

Adaptive immune responses. The adaptive arms of the immune system are composed of the humoral (antibody) and the cellular (T-cell) -mediated immunity. (top) Naïve CD4 ${ }^{+}$T cells can differentiate into follicular helper $\mathrm{CD} 4^{+} \mathrm{T}$ cells $\left(\mathrm{T}_{\mathrm{FH}}\right)$ or type 2 helper $\mathrm{T}$ cells $(\mathrm{Th} 2)$ that are involved in B-cell activation following antigenic stimulation. Through the interaction of CD40 on B cells with CD40L on CD4 T cells, B cells will then differentiate into plasma cells, which will produce antibodies against HIV, thus preventing the virus from infecting target CD4 T cells. (center) Naïve CD4 ${ }^{+}$T cells differentiate into type 1 helper T cells (Th1) that can activate $\mathrm{HIV}$-specific $\mathrm{CD}^{+} \mathrm{T}$ cells through the CD40/CD40L interaction. Activated $\mathrm{CD}^{+} \mathrm{T}$ cells mediate the killing of HIV-infected target $\mathrm{T}$ cells through the release of effector cytokines and molecules. (bottom) Naïve CD4 ${ }^{+} \mathrm{T}$ cells can differentiate into cytolytic $\mathrm{CD}^{+}{ }^{+} \mathrm{T}$ cells, which can directly kill infected targets. IFN- $\gamma$, interferon- $\gamma$; IL, interleukin. 
(1)

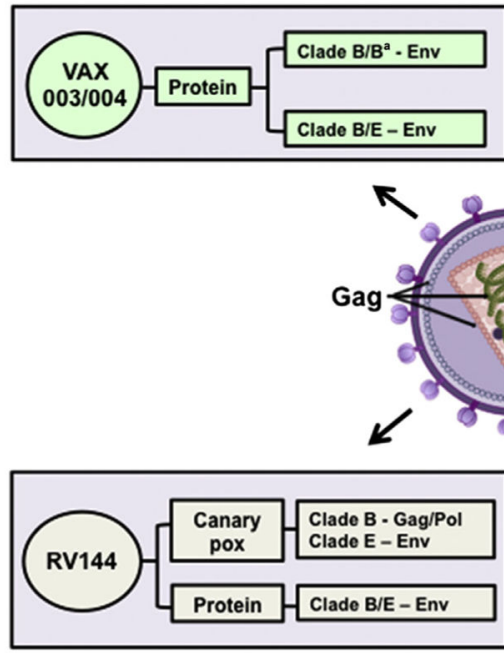

(3)
(2)
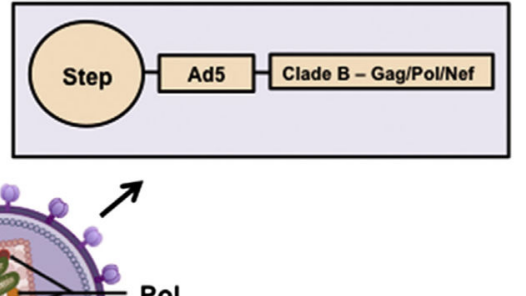

Env

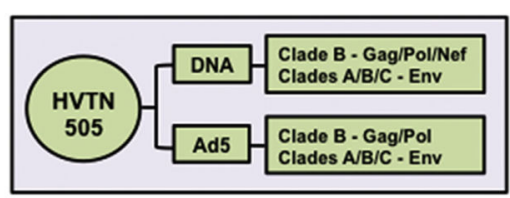

(4)

Fig. 2.

Clade-specific HIV-1 immunogens and their delivery vehicles used in the vaccine regimens tested for efficacy. The HIV-1 clades from which the immunogens were derived, the type of immunogen used, and the mode of vaccine delivery are shown for each of the 4 vaccine regimens. At the center is a simplified depiction of an HIV virion showing the major proteins used as immunogens. ${ }^{a}$ The bivalent clade B vaccine used in the VaxGen USA trial consisted of Env proteins from the MN and the GNE8 strains. 
(1)

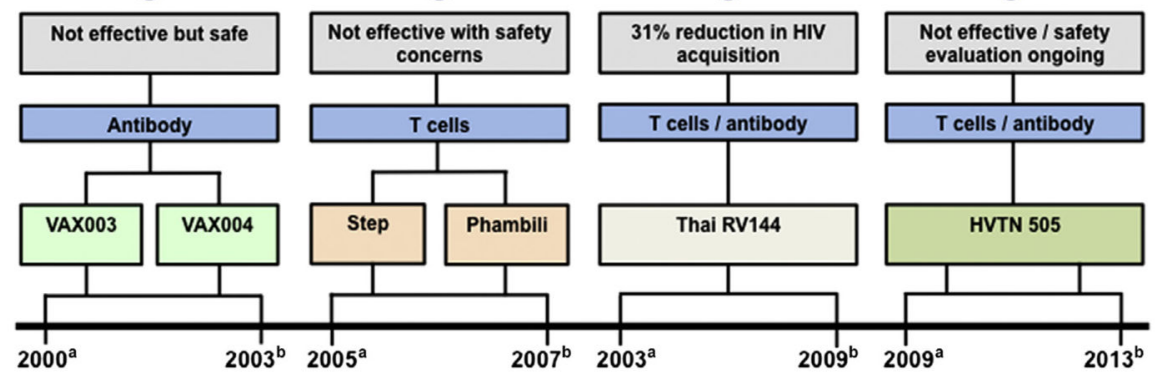

Fig. 3.

Safety and efficacy of the 4 HIV vaccine studies. The timeline for each of the 4 vaccines is shown in terms of which year any given trial started ${ }^{a}$ and ended ${ }^{b}$. The specific arms of the adaptive immunity measured are shown for each study. In addition, the safety and efficacy findings for each trial are summarized. 